International Journal of Agriculture, Environment and Bioresearch

Vol. 4, No. 06; 2019

ISSN: $2456-8643$

\title{
EFFECT OF PROCESSING METHODS OF GRADED LEVELS OF BAMBARA GROUNDNUT OFFAL (BGO) BASED DIETS ON GROWTH PERFORMANCE AND NUTRIENT DIGESTIBILITY OF BROILER CHICKEN
}

\author{
Torhemen, L. N. And Yainjoh, G.A. \\ Department Of Animal Nutrition, University Of Agriculture Makurdi, Pmb 2373, Makurdi, Benue State, Nigeria, \\ Department Of Agricultural And Natural Resources Makurdi Local Government Council Makurdi Benue State, \\ Nigeria \\ http://doi.org/10.35410/IJAEB.2019.4464
}

\begin{abstract}
An eight weeks (8) feeding trial was conducted to evaluate the growth performance and nutrient digestibility of broiler chickens fed diets containing $10 \%$ and $20 \%$ levels of heat processed and enzymes processed Bambara Groundnut Offal (BGO) diets. A total of 180 starter broiler chicks were assigned to five dietary treatments in a completely randomized design, each treatment was replicated three (3) times with twelve (12) birds per replicate. Five (5) experimental diets T1, T2, T3, T4 and T5 were formulated for the starter and finisher phase such that T1 had 0\% BGO and served as the control diet. T2 and T3 had 10\% and 20\% heat processed BGO respectively while T4 and T5 had 10\% and 20\% enzymes processed BGO respectively, and fed for 56days.

At the end of the finisher phase, three (3) birds from each dietary treatment were randomly selected and moved to metabolic cages and allowed to acclimatize for three (3) days, after which weighed amount of feed was fed to them daily and faecal samples collected daily for four (4) days, samples were oven dried weighed and sampled for digestibility analysis.

Results of the experiment indicate that, in both phases of the experiment no significant difference $(\mathrm{P}>0.05)$ in average final weight (AFW), total weight gain (TWG) and daily weight gain (DWG). There were significance differences $(\mathrm{P}<0.05)$ in average total feed intake (ATFI) and daily feed intake (DFI). Feed conversion ratio FCR was not significantly $(\mathrm{P}>0.05)$ affected at different levels of BGO inclusion in the two processing methods in both starter and finisher phase. Nutrient digestibility of dry matter, ether extract and nitrogen free extract was not significantly $(\mathrm{P}<0.05)$ affected. However, there were significant differences $(\mathrm{P}>0.05)$ in crude protein and crude fibre digestibility. Both processing methods of BGO at $10 \%$ and $20 \%$ inclusion rate did not have any adverse effect on broiler chicken production, however, 20\% heat processed BGO is recommended for reduced dietary cost.
\end{abstract}

Keywords: Bambara groundnut offal (BGO), Heat processed, Enzyme processed, growth performance, Nutrient digestibility, broiler chicken

\section{INTRODUCTION}

In the past few decades, there has been tremendous increase in the studies on utilization of agroindustrial by products in animal feeds because of the obvious need to conserve grains and 
legumes seeds for human feeding. There is also a growing need to explore the use of alternative feedstuff that is cheaper and locally available/accessible to replace the costly conventional feedstuff. Bambara groundnut offal is a potential feed material, it is a waste produced from the milling of bambara groundnut seed. It contains $17-21 \% \mathrm{CP}, 5-21 \% \mathrm{CF}$, and $12.44 \mathrm{MJ} / \mathrm{kg}$ gross energy, (Amaefule and Iroanya, 2004). However, the presence of anti-nutritional factors and high fibre content of bambara groundnut offal (BGO) are limitations to its use in poultry diets. There is a call for processing methods that can eliminate or reduce the level of anti-nutritional factors and also break the high fibre barrier since poultry is known for its inability to digest fibre (Alawa and Umunna, 1993). Processing method such as heat treatment is known to give BGO a sweet aroma, reduce or eliminate the adverse effect of anti-nutrient present in the material and improve digestibility of BGO based diets, by making some of the nutrients more available (Akande and Fabiyi, 2010). Other processing methods such as the addition of exogenous enzymes have also been identified to enhance digestibility and nutrient utilization. (Ani and Omeje, 2007).

This study was therefore conducted to investigate the response to processing methods of graded levels of BGO diets on growth performance and nutrient digestibility of broiler chickens.

\section{MATERIALS AND METHODS}

The experiment was carried out at the Poultry Unit of the College of Animal Science Teaching and Research Farm, Federal University of Agriculture Makurdi, Benue State of Nigeria. Benue state it situated at Southern Guinea Savannah belt of Nigeria between Latitude $6^{0}-8^{0} \mathrm{~N}$ and Longitude of $6^{0}-10^{\circ} \mathrm{E}$ and altitude of 97Meters elevation above the sea level, while Makurdi is particularly located on Longitude $7^{0} 43^{\prime} \mathrm{N}$ and Longitude $8^{0} 33^{\prime} \mathrm{E}$ (Microsoft Encarta, 2008).

\section{Preparation of test material (BGO)}

Bambara groundnut offal (BGO) was obtained from Okpa Sellers who process the bambara groundnut seed for the popular Okpa meal. BGO was heat processed by adding one liter of water to $5 \mathrm{~kg}$ of $\mathrm{BGO}$, this was mixed properly and set on fire in an open cast iron drying pan for 40 minutes at a temperature of about $100^{\circ} \mathrm{c}$. The BGO was steadily stirred to prevent it from sticking to the pan and burning until it turned brownish and produced a sweet smelling aromatic flavor (Udensi et. al. 2004; Ani, 2006). The heat processed BGO was removed and sprayed out to cool before incorporating into the diets. Another portion of BGO was also processed by adding $2 \mathrm{~g} / \mathrm{kg}$ diet of bio enzyme to the raw BGO and incorporated into the diets.

\section{Experimental diets}

Five (5) isonitrogenous and isocaloric starter and finisher experimental diets $\mathrm{T}_{1}, \mathrm{~T}_{2}, \mathrm{~T}_{3}, \mathrm{~T}_{4}$ and $\mathrm{T}_{5}$ were formulated as presented in table 1 and 2 respectively. $\mathrm{T}_{1}$ contained $0 \% \mathrm{BGO}, \mathrm{T}_{2}$ and $\mathrm{T}_{3}$ contained $10 \%$ and $20 \%$ heat processed BGO respectively to replace part of maize and soyabeans. While $\mathrm{T}_{4}$ and $\mathrm{T}_{5}$ contained $10 \%$ and $20 \%$ respectively $2 \mathrm{~g} / \mathrm{kg}$ diet of bio-enzyme processed BGO to replace part of maize and soya-beans in both starter and finisher phase of the experiment. 
Table 1: Percentage Ingredient Composition of Broiler Starter Diets Containing Graded Levels of Heat and Enzyme Processed Bambara Groundnut Offa1

Dietary Treatments

\begin{tabular}{|c|c|c|c|c|c|}
\hline \multirow[b]{2}{*}{ Ingredients } & \multirow[b]{2}{*}{$\mathrm{T}_{1} \mathbf{0 \%}$} & \multicolumn{2}{|c|}{ Heat processed } & \multicolumn{2}{|c|}{ Enzyme processed } \\
\hline & & $\mathbf{T}_{2} \mathbf{1 0 \%}$ & $\mathrm{T}_{3} \mathbf{2 0 \%}$ & $\mathbf{T}_{4} \mathbf{1 0 \%}$ & $\mathbf{T}_{5} \mathbf{2 0 \%}$ \\
\hline Maize & 33.00 & 26.44 & 19.90 & 26.44 & 19.90 \\
\hline Fill fat Soya-beans & 48.00 & 44.56 & 41.10 & 44.56 & 41.10 \\
\hline Maize Offal & 15.00 & 15.00 & 15.00 & 15.00 & 15.00 \\
\hline BGO & 0.00 & 10.00 & 20.00 & 10.00 & 20.00 \\
\hline Bone Meal & 3.20 & 3.20 & 3.20 & 3.20 & 3.20 \\
\hline Salt & 0.30 & 0.30 & 0.30 & 0.30 & 0.30 \\
\hline Premix & 0.25 & 0.25 & 0.25 & 0.25 & 0.25 \\
\hline Methionine & 0.25 & 0.25 & 0.25 & 0.25 & 0.25 \\
\hline Enzyme & - & - & - & ++ & ++ \\
\hline Total & 100 & 100 & 100 & 100 & 100 \\
\hline \multicolumn{6}{|c|}{ Calculated Nutrients } \\
\hline Crude Protein & 23 & 23 & 23 & 23 & 23 \\
\hline Crude fibre & 5.09 & 5.24 & 5.47 & 5.24 & 5.47 \\
\hline Ether Extract & 10.35 & 9.35 & 8.57 & 9.35 & 8.57 \\
\hline Lysine & 1.27 & 1.17 & 1.07 & 1.17 & 1.07 \\
\hline Methionine & 0.36 & 0.36 & 0.37 & 0.37 & 0.37 \\
\hline Calcium & 1.25 & 1.24 & 1.22 & 1.24 & 1.22 \\
\hline Phossphirus & 0.85 & 0.80 & 0.72 & 0.80 & 0.72 \\
\hline $\mathrm{ME}(\mathrm{kcd} / \mathrm{kg})$ & $3,091.56$ & $2,962.32$ & $2,901.80$ & $2,963.32$ & $2,901.80$ \\
\hline 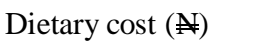 & 115.61 & 107.31 & 98.55 & 117.51 & 108.55 \\
\hline
\end{tabular}


Vol. 4, No. 06; 2019

ISSN: $2456-8643$

Table 2: Percentage Composition of Broiler Finisher Diets Containing Graded Levels of Heat Processed and Enzyme Processed Bambara Groundnut Offal

Dietary Treatments

\begin{tabular}{|c|c|c|c|c|c|}
\hline \multirow[b]{2}{*}{ Ingredients } & \multirow[b]{2}{*}{$\mathbf{T}_{1} \mathbf{0 \%}$} & \multicolumn{2}{|c|}{ Heat Processed } & \multicolumn{2}{|c|}{ Enzyme Processed } \\
\hline & & $\mathrm{T}_{2} \mathbf{1 0 \%}$ & $\mathbf{T}_{3} \mathbf{2 0 \%}$ & $\mathrm{T}_{4} \mathbf{1 0 \%}$ & $\mathrm{T}_{5} \mathbf{2 0 \%}$ \\
\hline Maize & 42.83 & 36.27 & 29.67 & 36.27 & 29.67 \\
\hline Fill fat Soya-beans & 37.77 & 34.33 & 30.93 & 34.33 & 30.93 \\
\hline Maize Offal & 15.00 & 15.00 & 15.00 & 15.00 & 15.00 \\
\hline BGO & 0.00 & 10.00 & 20.00 & 10.00 & 20.00 \\
\hline Bone Meal & 3.50 & 0.35 & 3.50 & 3.50 & 3.50 \\
\hline Salt & 0.40 & 0.40 & 0.40 & 0.40 & 0.40 \\
\hline Premix & 0.25 & 0.25 & 0.25 & 0.25 & 0.25 \\
\hline Methionine & 0.25 & 0.25 & 0.25 & 0.25 & 0.25 \\
\hline Enzyme & - & - & - & ++ & ++ \\
\hline Total & 100 & 100 & 100 & 100 & 100 \\
\hline \multicolumn{6}{|c|}{ Calculated Nutrients } \\
\hline Crude Protein & 20 & 20 & 20 & 20 & 20 \\
\hline Crude fibre & 4.85 & 5.04 & 5.23 & 5.04 & 5.23 \\
\hline Ether Extract & 8.90 & 8.02 & 7.15 & 8.02 & 7.15 \\
\hline Lysine & 1.06 & 0.95 & 0.85 & 0.95 & 0.85 \\
\hline Methionine & 0.31 & 0.34 & 0.34 & 0.34 & 0.34 \\
\hline Calcium & 1.40 & 1.40 & 1.39 & 1.40 & 1.39 \\
\hline Phossphirus & 0.89 & 0.86 & 0.81 & 0.86 & 0.81 \\
\hline $\mathrm{ME}(\mathrm{kcd} / \mathrm{kg})$ & $3,091.34$ & $2,996.39$ & $2,901.36$ & $2,996.38$ & $2,901.36$ \\
\hline Dietary cost $(\AA)$ & 113.29 & 104.54 & 96.00 & 114.74 & 106.00 \\
\hline \multicolumn{6}{|c|}{$\begin{array}{l}\text { Biomix premix supplied the following per } \mathrm{kg} \text { of diet Vitamin A 12,000,000I.U,Vitamin D33,000,000 I.U, Vitamin E 30,000mg, Vitamin K } \\
2,500 \mathrm{mg} \text {, Folic acid } 1,000 \mathrm{mg} \text {, Niacin 40,000mg,Calpan 10,000mg,Vitamin B2 } 5,000 \mathrm{mg} \text {,Vitamin B12 } 20 \mathrm{mg} \text {,Vitamin B1 } 2,000 \mathrm{mg} \text {,Vitamin B }\end{array}$} \\
\hline www.ijaeb.org & & & & & Page 1 \\
\hline
\end{tabular}


3,500mg,Biotin $\quad 80 \mathrm{mg}$,Antioxidant 125,000mg,Cobalt 250mg,Selenium 250mg ,Iodine 1,200mg,Iron 40,000mg, Manganese 70,000mg,Copper $8,000 \mathrm{mg}$,Zinc 80,000mg, Choline Chloride 200,000mg, ++= Bioenzyme ( $2 \mathrm{~g} / \mathrm{kg}$ diet $),-=$ heat processed.

Experimental design and management

A total of one hundred and eighty (180) day old broiler chicks having an initial weight of $37 \mathrm{~g} /$ bird were used in the experiment which lasted for eight (8) weeks. Birds were randomly allotted to five dietary treatments each replicated three (3) times. Birds were housed in clean washed and disinfected pens with a litter material of wood shelving of about $2-3 \mathrm{~cm}$. On arrival, birds were given vitalyte in water as anti stress. Water and feed was given daily. During the brooding phase, chicks were supplied with heat from electric bulb and or charcoal stove, heat was gradually reduced based on the response of the chicks and eventually withdrawn. Routine vaccination typical to broiler chickens was strictly adhered to, while maintaining good hygiene management practices.

\section{Data Collection}

The initial body weight of the birds was taken at the beginning of the experiment, subsequently measurements such as average daily weight gain (ADWG) average total weight gain (ATWG) final body weight (FBW) average daily feed intake (ADFI), average total feed intake (ADFI) feed conversion ratio (FCR) and mortality rate (MR) were obtained. Nutrient digestibility was determined by the use of three (3) birds from each dietary treatment which were randomly selected and starved over night (12hours) after which a weighed amount of feed was offered daily and fecal samples collected for 4days, oven dried, milled and analyzed for dry matter, crude fibre, crude protein, ether extract and nitrogen free extract using standard methods of AOAC, 1995.

All data collected were subjected to analysis of variance using the procedure of Steel and Torrie (1980), where significant differences were observed, treatment means were separated using Duncan multiple range test (Duncan, 1955).

\section{RESULT AND DISCUSSION}

The experimental diets contained $23 \%$ and $20 \%$ crude protein for the starter and finisher phase respectively as shown in Tables 1 and 2. Metabolisable energy for both phases was in the range of $2900-3000 \mathrm{Kcal} / \mathrm{kg}$. This is in line with the protein and energy requirements of broiler chicken as recommended by NRC (1997).

Growth performance of starter broiler chicken fed (BGO) diets is presented in Table 3, while that of finisher is presented in Table 4. 
Vol. 4, No. 06; 2019

ISSN: $2456-8643$

Table 3: Effect of Feeding Diets Containing Graded Levels of Heat Processes and Enzyme Processed BGO on Growth Performance of Broiler Starter Chickens.

Dietary Treatments

\begin{tabular}{|llllllll|}
\hline & \multicolumn{3}{c}{ Heat Processed } & \multicolumn{2}{c}{ Enzyme Processed } \\
Parameters (g) & $\mathbf{T}_{\mathbf{1}}(\mathbf{0 \%})$ & $\mathbf{T}_{\mathbf{2}}(\mathbf{1 0 \%})$ & $\mathbf{T}_{\mathbf{3}}(\mathbf{2 0 \%})$ & $\mathbf{T}_{\mathbf{4}}(\mathbf{1 0 \%})$ & $\mathbf{T}_{\mathbf{5}}(\mathbf{2 0 \%})$ & SEM & LS \\
\hline Average Initial weight & 37.50 & 37.50 & 37.50 & 37.50 & 37.50 & 00 & NS \\
Average final weight & 638.89 & 656.16 & 704.29 & 676.39 & 700.00 & 14.19 & NS \\
Average total weight & 601.39 & 618.66 & 666.79 & 638.89 & 662.50 & 14.19 & NS \\
Average daily weight & 21.48 & 22.10 & 23.81 & 22.82 & 23.66 & 0.51 & NS \\
Average total feed intake & $963.89^{\mathrm{c}}$ & $1012.32^{\mathrm{bc}}$ & $1087.44^{\mathrm{a}}$ & $1042.36^{\mathrm{ab}}$ & $1079.17^{\mathrm{a}}$ & 14.08 & $*$ \\
Average daily feed intake & $34.42^{\mathrm{c}}$ & $36.16^{\mathrm{bc}}$ & $38.84^{\mathrm{a}}$ & $37.23^{\mathrm{ab}}$ & $38.54^{\mathrm{a}}$ & 0.50 & $*$ \\
Feed conversion ration & 1.60 & 1.64 & 1.63 & 1.63 & 1.63 & 0.01 & $\mathrm{NS}$ \\
Mortality (\%) & 0.00 & 8.33 & 5.55 & 0.00 & 0.00 & 2.48 & $\mathrm{NS}$ \\
\hline
\end{tabular}

abc means within the same row with different superscripts are significantly different $(\mathrm{P}<0.05) \mathrm{T}_{1}=$ control $0 \% \mathrm{BGO}, \mathrm{T}_{2}=10 \%$ heat processed $\mathrm{BGO}, \mathrm{T}_{3}=20 \%$ heat processed $\mathrm{BGO}, \mathrm{T}_{4}=10 \%$ enzyme processed $\mathrm{BGO}, \mathrm{T}_{5}=20 \%$ enzyme processed $\mathrm{BGO}$. $\mathrm{g}=$ gram, $\mathrm{SEM}=$ standard error mean, $\mathrm{LS}=$ level of significance, $\mathrm{BGO}=$ Bambara Groundnut Offal *= significance, NS= Not significant.

Table 4: Effect of Feeding Diets Containing Graded Levels of Heat Processed/Enzyme Processed BGO on Performance of Broiler Finisher Chickens.

Dietary Treatment

\begin{tabular}{|c|c|c|c|c|c|c|c|}
\hline \multirow[b]{2}{*}{ Parameters (g) } & \multirow[b]{2}{*}{$\mathbf{T}_{1}(\mathbf{0 \%})$} & \multicolumn{2}{|c|}{ Heat Processed } & \multicolumn{2}{|c|}{ Enzyme Processed } & \multirow[b]{2}{*}{ SEM } & \multirow[b]{2}{*}{ LS } \\
\hline & & $\begin{array}{l}T_{2} \\
(10 \%)\end{array}$ & $\begin{array}{l}T_{3} \\
(20 \%)\end{array}$ & $\begin{array}{l}T_{4} \\
(10 \%)\end{array}$ & $\begin{array}{l}\mathrm{T}_{5} \\
(20 \%)\end{array}$ & & \\
\hline Average Initial weight & 638.87 & 656.16 & 704.30 & 676.39 & 700.00 & 14.19 & NS \\
\hline Average final weight & 1842.30 & 1887.92 & 2012.38 & 1913.39 & 2083.33 & 38.83 & NS \\
\hline Average total weight gain & 1243.41 & 1231.75 & 1308.08 & 1237.50 & 1383.33 & 35.76 & NS \\
\hline Average daily weight gain & 42.98 & 43.99 & 46.71 & 44.20 & 49.40 & 1.28 & NS \\
\hline Average total feed intake & $2533.47^{\mathrm{b}}$ & $2453.88^{b}$ & $3128.53^{\mathrm{a}}$ & $2883.34^{\mathrm{ab}}$ & 3273.91 & 104.21 & $*$ \\
\hline Average daily feed intake & $90.48^{\mathrm{b}}$ & $87.64^{\mathrm{b}}$ & $111.73^{\mathrm{a}}$ & $102.98^{\mathrm{ab}}$ & $116.92^{\mathrm{a}}$ & 3.72 & $*$ \\
\hline Feed conversion ration & 2.11 & 1.99 & 2.39 & 2.33 & 2.37 & 0.01 & Ns \\
\hline
\end{tabular}


Vol. 4, No. 06; 2019

ISSN: $2456-8643$

Mortality (\%)

2.78

11.11

5.55

0.00

0.00

3.73

Ns

abc means within the same row with different superscripts are significantly different $(\mathrm{P}<0.05) \mathrm{T}_{1}=$ control $0 \% \mathrm{BGO}, \mathrm{T}_{2}=10 \%$ heat processed $\mathrm{BGO}, \mathrm{T}_{3}=20 \%$ heat processed $\mathrm{BGO}, \mathrm{T}_{4}=10 \%$ enzyme processed $\mathrm{BGO}, \mathrm{T}_{5}=20 \%$ enzyme processed $\mathrm{BGO}$. $\mathrm{g}=\mathrm{gram}$, SEM=standard error mean, LS=level of significance, BGO=Bambara Groundnut Offal *= significance, NS= Not significant.

Table 5: Effect of Feeding Diets Containing Graded Levels of Heat Processed and Enzyme Processed BGO on Nutrient Digestibility of Broiler Finisher Chicken

\section{Dietary Treatment}

\begin{tabular}{|llllllll|}
\hline & \multicolumn{5}{c}{ Heat Processed } & \multicolumn{2}{c|}{ Enzyme Processed } \\
Parameters $(\mathbf{g})$ & $\mathbf{T}_{\mathbf{1}}(\mathbf{0 \%})$ & $\mathbf{T}_{\mathbf{2}}(\mathbf{1 0 \%})$ & $\mathbf{T}_{\mathbf{3}}(\mathbf{2 0} \%)$ & $\mathbf{T}_{\mathbf{4}}(\mathbf{1 0 \%})$ & $\mathbf{T}_{\mathbf{5}}(\mathbf{2 0 \%})$ & $\mathbf{S E M}$ & $\mathbf{L S}$ \\
\hline Dry matter & 73.65 & 68.24 & 65.97 & 72.35 & 65.99 & 1.37 & $\mathrm{NS}$ \\
Crude protein & $59.85^{\mathrm{a}}$ & $48.22^{\mathrm{ab}}$ & $47.10^{\mathrm{b}}$ & $60.27^{\mathrm{a}}$ & $49.83^{\mathrm{ab}}$ & 2.09 & $*$ \\
Crude fiber & $66.83^{\mathrm{a}}$ & $56.74^{\mathrm{a}}$ & $35.76^{\mathrm{c}}$ & $48.27^{\mathrm{ab}}$ & $32.51^{\mathrm{b}}$ & 3.72 & $*$ \\
Ether extract & 84.26 & 84.62 & 85.18 & 88.21 & 84.14 & 0.97 & $\mathrm{NS}$ \\
Nitrogen free extract & 81.91 & 80.15 & 79.39 & 82.15 & 77.58 & 0.93 & $\mathrm{NS}$ \\
\hline
\end{tabular}

abc means with different superscripts along the same row are significantly $(\mathrm{p}<0.05)$ different. SEM=standard error of mean significant difference. $\mathrm{NS}=$ not significant. $\mathrm{LS}=$ level of significant. $*=$ significant difference.

The effect of experimental diets on the growth response of broiler starter and finisher chickens is presented in table 3 and 4 respectively. It was observed that the diets had no significant $(\mathrm{p}>0.05)$ effect on average final weight, total weight, daily weight gain, feed conversion ratio and percentage mortality. There were significant differences $(\mathrm{p}<0.05)$ in average total feed intake and daily feed intake in both processing methods. These observed performance can be attributed to the effective processing methods of the BGO diets despite the increasing levels of BGO inclusion. This led to the comparable performance of the birds on the test diets with birds on the control diet. This result disagrees with that of Ekenyem and Onyeagoro (2006) and Mabuike and Ekenyem(2001) who reported that higher levels of fibre in monogastric diets depress weight gain. The significant difference observed in average total feed intake and average daily feed intake in both phases of the experiment can be attributed to increasing need to meet the necessary nutrient requirement for increased weight gain since high fibre diets turn to dilute energy content of feeds thereby causing increase in feed consumption. This result is in agreement with that of Isikwenu et. al. (2000) who reported increased feed intake with increase in fibre content. Results of this study however disagrees with reports of Kung and Grueling (2000) who reported that fibre limit the amount of feed intake and the retention of available nutrients by the bird and contributes to excessive nutrient excretion. Birds fed $20 \%$ BGO at both processing methods performed better than the $10 \%$ BGO inclusion rate. However, in the starter phase numerical values showed that birds fed $20 \%$ enzyme processed BGO diets consumed less feed compared to the $20 \%$ heat processed group. This result agrees with that of Ranada and Rajimane (1992), 
Samarasingh et. al. (2000) and Ani and Omeje (2007) who reported that, enzyme supplementation of poultry diets results in decrease in feed intake. In the finisher phase numerical values of average total feed intake and average daily feed intake of the $20 \%$ enzyme processed BGO diets disagrees with result of Randa and Rajimane (1992), Samarasingh et.al. (2000) and Ani and Omeje (2007) because birds on 20\% enzyme processed BGO consumed more feeds.

Feed conversion ratio FCR and percentage mortality MR were not significantly ( $p>0.05)$ affected in both phases of the experiment. These suggest that all dietary treatments were efficiently utilized and had no adverse nutritional effect as evident in the non significant report of the diets on mortality rate. Toasting of BGO could have also improved the utilization of diets through the action of heat treatment and also the use of exogenous enzyme which has been shown to reduce viscosity of gut content and improve the utilization of nutrients. (Acamovic 2001; Carsten 2013).

Table 5 presents the digestibility of broiler finisher chickens. Dry matter, ether extract and nitrogen free extract digestibility of finisher chickens fed graded levels of heat processed and enzyme processed BGO diets were not significantly $(\mathrm{p}>0.05)$ affected. However, dry matter, ether extract and nitrogen free extracted digestibility values of birds on enzyme processed BGO diets was higher. Significant differences $(p<0.05)$ occurred in digestibility of crude protein and crude fibre for both processing methods. Crude protein digestibility of enzyme processed at $10 \%$ BGO inclusion rate was comparable with the control. This is traceable to the interactive effect between the bird's digestive system and the exogenous enzyme activity. This result agrees with results of Bedfort (1997) who reported increased digestibility as a result of exogenous enzyme supplementation. Crude fibre digestibility of both processing methods of BGO at $10 \%$ inclusion rate was comparable with the control. This is attributed to the processing methods which were capable of breaking down the tolerable level of fibre encapsulating the more soluble constituents for easy digestion by the birds thereby enhancing the digestibility of other nutrients. It was observed that digestibility of crude protein and crud fibre decreased with increase in BGO inclusion rate despite the processing methods. This is in agreement with results of Ani (2000) who reported that poultry cannot utilize high fibre diets fully because they lack the digestive framework.

\section{CONCLUSION AND RECOMMENDATION}

In conclusion the study revealed that, bambara groundnut offal (BGO) which is a waste product can be enhanced as feed for broiler chicken production to replace part of maize and soyabeans through processing methods of BGO such as heat application (Toasting) and enzyme supplementation even at higher levels of fibre content. In addition to improved performances, $20 \%$ heat processed $\mathrm{BGO}$ is recommended for reduced dietary cost.

\section{REFERENCES}

Acamovic, T. (2001). Commercial Application of Enzyme Technology for Poultry Production. World's poultry science journal 57:225-242.acs.org. 
Akande, K.E; and Fabiyi, E.F (2010). "Effect of Processing Methods on some Anti-nutritional factors in Legume Seeds for Poultry Feeding". International journal of poultry science 9 (10): $996-1001$.

Amaefule, K. U. and Iroanya, C. O. (2004). Replacement of soyabean meal and Maize offal with Bambara groundnut offal in Broiler Diets. Nigerian Agric. Journal;35:133-142

Ani, A.O (2006). "Effect of Toasted Bambara nut (voadseia subterranean L) waste on Haematology, Carcass and Organ characteristics of Growing Rabbits". Proc. $31^{\text {st }}$ annual conference of the Nigerian. Society for Animals production (NSAP), 341-345, Kano Nigeria.

Ani, A. O and Omeje, O.D (2007). Response of Broiler Finishers to Graded Levels of Raw Bambara nut (vigna subterranean) $(L)$ verd ) Waste and Supplementary Enzyme. Tropical journal of Animal Science, 2007 vol. 10, Nos 12. 281-288.

AOAC (1990). Association of Official Analytical Chemists. Official Methods of Analysis. $5^{\text {th }}$ Ed. Washington.D.C.1230.

Bedfort, M. R (1997), "Mechanism of Action and Potential Environmental Benefits from the use of Feed Enzyme. Annual Feed Science Technology. 53:145-155".

Duncan D.B (1955). New Multiple Range Test Biometrics 11:1-42.

Samarasinhe, K; Messikommer, R. and Wenk, (2000). "Activity of Supplementation Enzyme and their effect on Nutrient utilization and Growth Performance of Growing Chickens as affected by Pelleting Temperature" Arch. Anim. Nutria. 53:45-58.

Carsten, P. (2013). Reduction of Anti-nutritional factors in (pre) starter Feed. All about feed (international magazine on animal nutrition, processing and feed management). Vol. 21,No.2 2013 Pp 25-27.

Isikweun, J.O; Udeh, I and Ifie, I. (2012). Haematological Response, performance and Economic Analysis of Cockerel Chicks fed Enzyme Supplemented Brewer's Dried Grains, Groundnut Cake Based Diets. Pakistian journal of Nutrition II (6):541, 2012.

Kung, P. Grueling H.T (2000). Enzyme Supplementation of Poultry Diet containing rye and wheat. British journal of Nutrition. 62:139-149.

Ranade, A. B and Rajmane, B.V (1992). Effect of Enzyme Feed Supplement on Commercial Broilers. Proceeding of the $9^{\text {th }}$ world poultry congress, Amsterdam, Netherlands WPSA. Pp 485-487.

Steel, R.G. D and J. H Torrie (1980). Principles and Procedures of Statistic. A Biometric Approach. $2^{\text {nd }}$ ed. New York: McGraw-Hill publishers.

Madubuike, F.N and Ekenyem, B. U (2001). Non Ruminat Livestock production in the Tropics. Gust chuks Graphic centre, Owerri, Nigeria, 196. 
Udensi, E. A; Onwuka, G. T and Okoli, E.G (2004) "Effect of Processing on the Levels of some Anti-nutritional factors in Mucunautilis" Plant Products Research journal 8 (1):1-6.

Alawa, J. P and Umunna, N.N. 1993. Alternative Feed Formation Developing Countries, Prospects of Utilization of Agro-industrial by products. Journal of Animal Production Research 13 (2):53-87.

Onyimonyi, A.E and Okeke, G.C (2007). Assessment of the Practical Potential of Bambara (vigna Thouars) waste for wearner pigs. Pakistan journal of Nutrition 6(3):264-266.

Ekenyem, B. U and Onyeagoro, C. P. (2006). Replacement of Bambara (vigna subterranean) sievata for soyabean meal(Glycine max) on the performance of Finishers Broiler Chicken. International journal of poultry science; 5:381-384

National Research Council (NRC) 1997. Nutrient Requirements of Animals. Eight Revised Ed. 1979 National Academy Press. Washington DC.1979.

Microsoft Encarta (2008). Microsoft Corporation. 